\title{
Uncertainty, Financial Development and FDI Inflows: France Evidence
}

\section{Francois Smith}

University of Bordeaux, France.

Email:Francois.Smith@u-bordeaux.fr

\begin{abstract}
The economic policy and world uncertainties are negatively effects on the whole economy, specifically on the financial sector of France. The outbreak of corona virus in the last quarter of 2019 makes the situation worst, specifically for the case of France. The outbreak of this virus results in a drastic reduction in liquidity and solvency of French corporations. The inflows of foreign direct investment (FDI) in France are also reduced by $17 \%$ during the outbreak of virus. However, after analyzing the situation of world uncertainty and economic policy uncertainty in France, it is found to be crucial to examine the role of economic policy and world uncertainties in defining FDI and financial development. Present study thus attempts to investigate the impact of economic policy uncertainty and world uncertainty on FDI and financial development in France. For this purpose, the study collects the data for the period of 1997-2018 from different secondary data sources. The study applied ARDL bound testing approach to estimate the results. Findings report negative impact of economic policy uncertainty and world uncertainty on FDI and financial development. The study suggests the France government to monitor the sources and size of uncertainty shock while formulating different economic policies.
\end{abstract}

Keywords: Economic policy uncertainty, World uncertainty, Foreign direct investment, Financial development, France.

\section{Introduction}

Since the publication of "The Age of Uncertainty" in 1977, many major events have been occurred that result in an economic and political uncertainty around the globe (Al-Thaqeb \& Algharabali, 2019). This globalization or uncertainty is highly aligned with the fact that we exist in the "hyper-connected" world, where an event which arises in one part of the world will definitely have an influence on the other part of the world (French \& Li, 2021). Evidences reveal that financial crises of 2008, Arab springs of 2012, and European sovereign debt crises of 2010 are the underlying causes of increased economic, political and world uncertainties around the globe. Hence, many researchers have started conducting their research to explore the effects of these uncertainties on the macroeconomy. Specifically, the effects of economic policy uncertainty (EPUC) on financial variables have received a lot of attention of economic researchers.

Researchers indicated the adverse and detrimental effects of these uncertainties on the whole economy. The particular literature shows that higher level of EPUC in a nation reduces production (Mian \& Sufi, 2010) investment (Shen, Zhang, Liu, \& Hou, 2020) stocks (Hu, Kutan, \& Sun, 2018) inflow of capital (Wang, Luo, Wang, $\mathrm{Xu}, \& \mathrm{Wu}, 2021)$ trade credit (Godil, Sarwat, Sharif, \& Jermsittiparsert, 2020) and financial stability (Phan, Iyke, Sharma, \& Affandi, 2021). It is argued that financial sector of a country plays an important role in its economic development. The inflow of capital and domestic credit to private sector are two pillars of the financial sector which is highly affected with the EPUC and world uncertainty (WUC). The outbreak of corona virus in the last quarter of 2019 make the situation more worst, specifically for the case of France. The outbreak of this virus results in a drastic reduction in liquidity and solvency of French corporations (see Figure 1). The inflows of FDI also reduces by $17 \%$ during the outbreak of virus (see Figure 2). Hence, researchers indicated that the global pandemic is another cause of world and economic policy uncertainty. This scenario motivates the authors to investigate the effect of EPUC and WUC on the FDI and financial development (FNDP) of France.
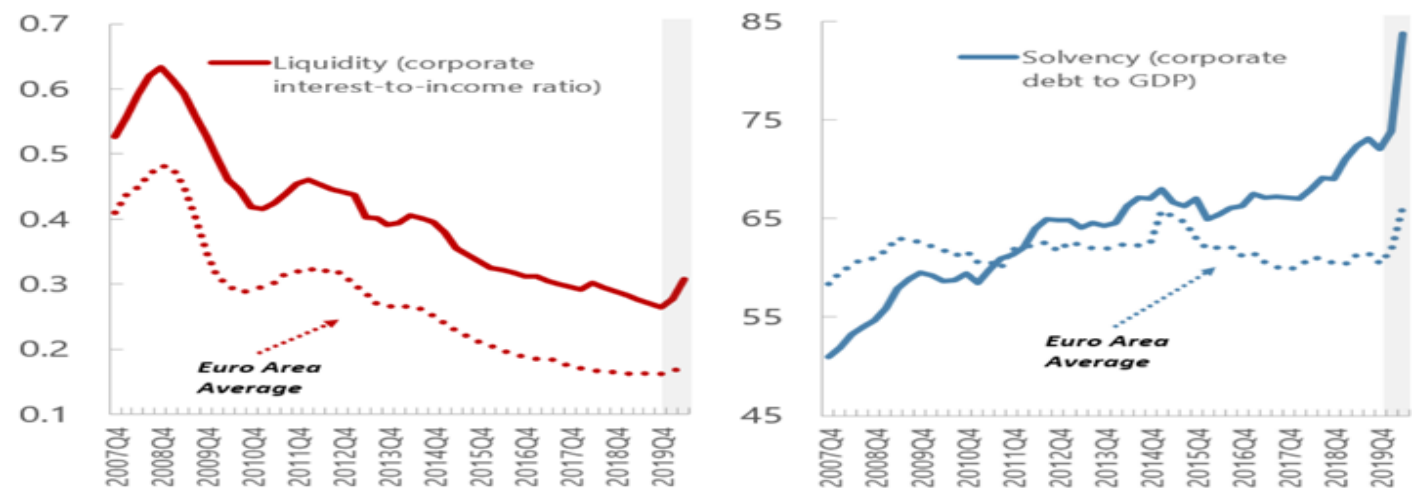

Figure-1. Reduction in Liquidity and Solvency of France Corporations. 


\section{FDI dropped 17\% in France in 2020 \\ Number of FDI projects in France, 2014-20}

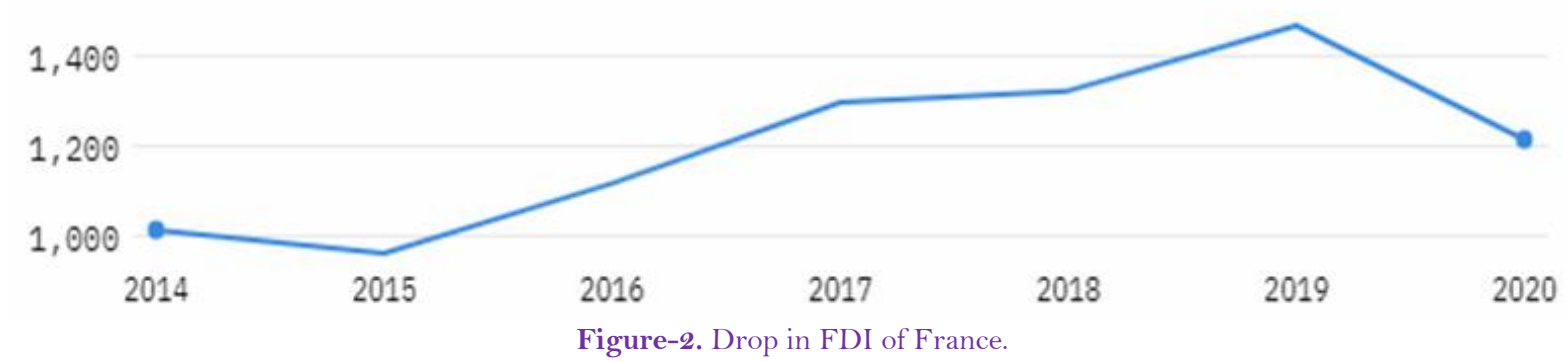

Researchers have extensively worked on the inflows of foreign capitals as FDI plays a very important role in promoting the economic growth. Many researchers have spent their days and nights in finding the determinants of FDI. One of the most crucial determinant which captures the importance of different researchers and policy makers is "uncertainty". This uncertainty can be of any type (i.e., it can be economic, political, social, economic policy or world uncertainty). Uncertainty arises when the economic body cannot envisage whether, when and how the government will change its current economic policy (Goodell, McGee, \& McGroarty, 2020). Researchers indicated that higher level of EPUC reduces the inflows of capital as EPUC is a signal of a limited protection from host nation's legal and political institutions (Albulescu, Demirer, Raheem, \& Tiwari, 2019). It also reduces the return on stock markets, and this effect is more persevering during the high volatility periods (Liow, Liao, \& Huang, 2018). According to the world investment report, EPUC is among those factors that hinder the recovery of FDI. Thus, it is concluded that EPUC is very detrimental for the FDI.

Economic or world uncertainty do not only reduce the inflows of FDI, but also plays a negative role in the financial development. It also reduces the liquidity and solvency of the corporations (Zhao, 2020) and bank credit growth (Ashraf \& Shen, 2019) which is again a biggest threat for the financial development because banks and corporations contribute $20 \%$ in the financial development of the nation. According to Avom, Njangang, and Nawo (2020) 1-unit of increase in WUC tends to reduce 12\%-16\% FNDP of the nation. Hence, the present study concluded that EPUC and WUC is having adverse effects on FNDP. However, after analyzing the situation of economic policy and world uncertainty of France since 1997 (see Figures 3 and 4 respectively), present study proposes that it is crucial to investigate the impact of EPUC and WUC on the FDI and FNDP of China. It is very surprising for the authors that until now this relationship has not been investigated by the prior researchers. Hence, present study contributes to the existing debate of uncertainties by analyzing the role of EPUC and WUC on the FDI and FNDP for the context of France.

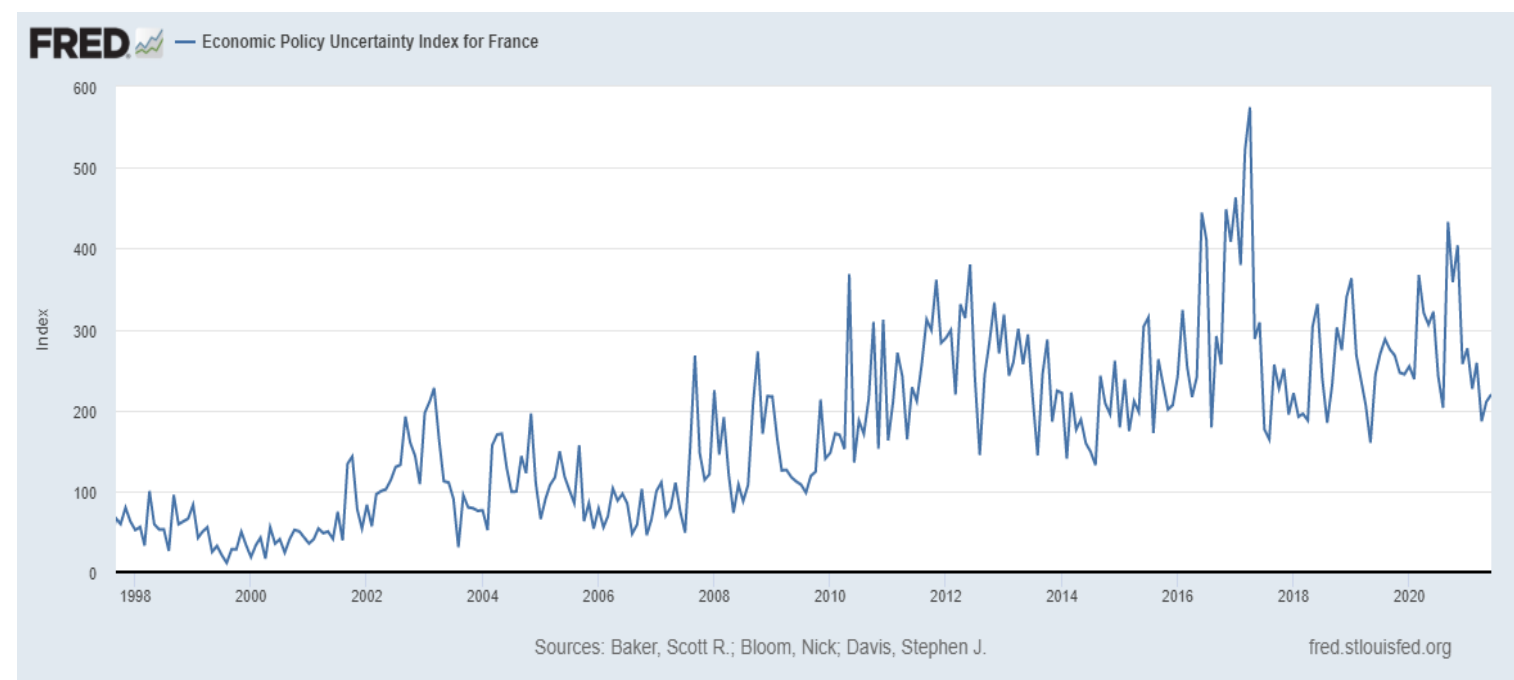

Figure-3. Economic policy uncertainty index.

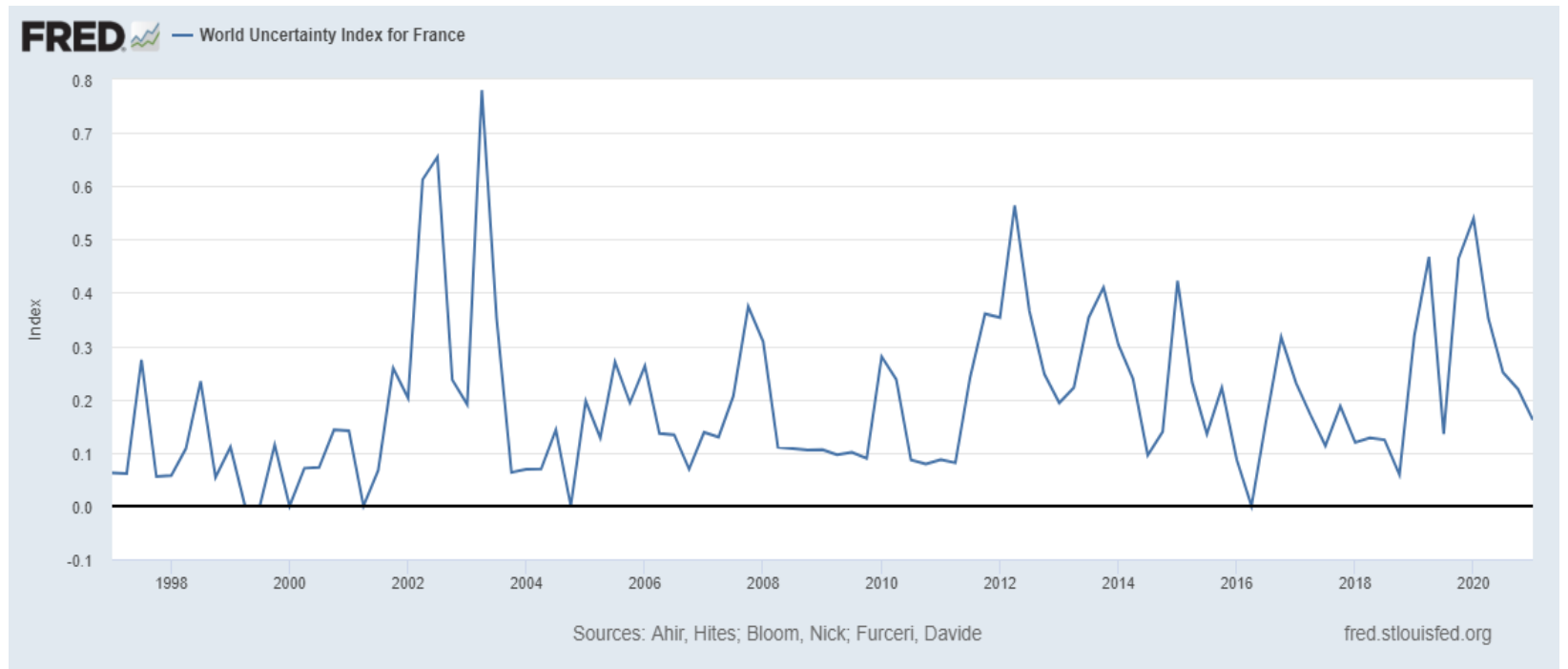

Figure-4. World uncertainty of France. 


\section{Literature Review}

This section reviews the existing literature of the study along with the development of hypothesis. The conceptual model of the study is also highlighted in this section. The effects of time capricious uncertainty on the macro-economy have received a considerable attention in the recent years. Many researchers have predicted the negative role of uncertainty on different macro-economic variables. Specifically, the effects of economic policy uncertainty (EPUC) on financial variables have received a lot of attention of economic researchers. For instance, Azam, Khan, and Iqbal (2012) analyzed the impact of EPUC on FDI for the case of South Asian economics by utilizing the data from 1990-2018. The study applied ARDL to analyze the short run and long run impact of EPUC on FDI. The findings of the study reveal the insignificant relationship between EPUC and FDI in short run while significant and negative relationship between EPUC and FDI in long run. The study states that increase in the level of EPUC increases the political and financial risk which is detrimental for the inflows of FDI. Busse and Hefeker (2007) analyzed the role of political uncertainty in FDI for the case of 84 developing economies and showed the negative role of political uncertainty in the inflows of FDI. The study concluded that political uncertainty is a severe intimidation for the contract of investment that is signed between host country and international bodies. Hence, the yield on capital can be depreciated in the nations having more chances of political risk.

Drobetz, El Ghoul, Guedhami, and Janzen (2018) examined the empirical relationship between WUC and FDI by using world uncertainty index as a measurement of world uncertainty. In this regard, the study gathered data of 45 developed and developing economies for the period of 1990-2018. The study indicated the negative link between WUC and FDI. Phan et al. (2021) investigated the impact of EPUC on financial instability for the case of 23 nations for the period of 1996-2016 and indicated the negative bond between these variables. The study implies that 1-standardize unit of increase in EPUC tends to reduce the financial stability between $3.73 \%$ to $8.02 \%$ for the selected nations. The study concluded that this impact is strongest for the nations with advanced competition, small regulatory capital and smaller financial systems. Canh, Binh, Thanh, and Schinckus (2020) investigated the role of EPUC in the financial sector of Malaysia and indicated the detrimental role of EPUC in the financial development of the selected nation. The study concluded that high level of EPUC substantially reduces the bank lending growth with its stronger influence of large sized and riskier banks. Caglayan and Xu (2019) analyzed the influence of EPUC on the stability of credit and financial institutions. For this purpose, the study gathered the data of 18 developed economies for the period of 1994-2013 and indicated the negative trade-off between the selected variables. The study provides the strong evidence that uncertainty diminishes the availability of credit and leads to an increase in the non-performing loans of banks. This concluded the detrimental role of EPUC on the financial development of the nation and indicated that EPUC not only having its detrimental effects for the developing economies, but also for the developed economies.

Choi, Furceri, and Yoon (2021) studied the effects of WUC on the financial system of 13 OECD economies. For this purpose, the study collected the data for the period of 2000-2015 and indicated the adverse effects of WUC on the financial system of the selected economies. Avom et al. (2020) analyzed the role of WUC on the FNDP of 139 developing and emerging economies and indicated the negative connection between these variables. The study concluded that increased WUC is aligned with many other uncertainties i.e., financial uncertainty, political and economic uncertainty etc. which are very detrimental for the financial systems, and thus, negatively contributes to the FNDP. The study implies that $1 \%$ of increase in WUC tends to reduce $12 \%-16 \%$ FNDP. Li and Zhong (2020) conducted their research in the context of China and analyzed the role of EPUC on the financial development of China for the period of 1995-2016. the study measures EPUC by global economic uncertainty index, while financial development with financial condition index. The study used EPUC as independent while FNDP as a dependent variable of the study. Results of the study indicated the negative relationship between these variables. Shi, Qiu, and Fan (2020) examined the empirical relationship between WUC and FDI for the case of 35 Asian economies for the period of 2000-2018. The study applied VAR model to analyze the empirical results. Results of the study showed adverse impacts of WUC on the inflows of FDI in the host country.

Abaidoo (2019) analyzed the role of economic, political and world uncertainty in the inflow of FDI and imports for the case of China. For this purpose, the study collected the data from 1990-2015 and applied ARDL model to estimate the coefficients. The study used different uncertainty dimensions (i.e., economic policies and world uncertainty) as explanatory variables. Results of the study did not reveal any significant association between the chosen variables in short run, while the study indicated the significant negative rapport between the chosen variables in long run. The study concluded that the uncertainties are very detrimental for the foreign inflows. Demir and Ersan (2018) conducted their research on Turkey and analyzed the influence of WUC on its financial markets for the period of 2003-2014. The Study indicted the negative role of WUC on the financial markets. Debata and Mahakud (2018) analyzed the role of EPUC on the stock market development of 25 developing economies by incorporating the moderating role of financial crises. The study indicated the negative influence of EPUC on the stock market development for the selected countries which become more negative in the presence of financial crises. The study concluded the enhancing role of financial crises in the nexus between EPUC and stock market development.

Guo, Wei, Zhong, Liu, and Huang (2020) indicated that EPUC arises when the economic body cannot envisage whether, when and how the government will change its current economic policy. Author indicated that EPUC having significant impacts on the behavior of different financial and market bodies of the country, especially related to the financial decision making i.e., investment decisions. Hence, this importance of the EPUC motivated the authors to conduct their research in the uncertainty-financial market nexus. In this regard, the study gathered the data of China for the period of 1990-2018 and applied ARDL to estimate the results. Results reveal that uncertainty in the economic policies is very unfavorable for the financial markets. Henceforth, the study concluded the negative link between chosen variables. Wu, Zhang, Zhang, and Zou (2020) examined the role of economic, financial, political, and pandemic uncertainty on the inflows of foreign capital for the case of South Asian Economies. In this regard, the study gathered the data for the period of 1990-2017. The study applied ARDL and revealed the adverse (negative) impact of economic, financial, political, and endemic uncertainty on the foreign inflows of capital. In 
addition, the study indicated that the impact of economic uncertainty is more adverse as compare to other uncertainties. Liu and Dong (2020) also indicated the adverse effects of pandemic and economic uncertainty on the inflow of capitals. Nguyen, Kim, and Papanastassiou (2018) used the firm level data across 25 economies for the period of $1996 \mathrm{Q} 1$ to $2016 \mathrm{Q} 1$ to analyze the role of WUC in foreign inflows and trade credit provisions. The study indicated that increase in WUC tends to reduce the foreign inflow of capital and provision of trade credit. After reviewing the above literature, present study hypothesized that:

$H_{1}$ : Economic policy uncertainty has negative impact on foreign direct investment.

$H_{2}$ : Economic policy uncertainty has negative impact on financial development.

$H_{3}$ : World uncertainty has negative impact on foreign direct investment.

$H_{4}$ : World uncertainty has negative impact on financial development.

\subsection{Conceptual Model}

The conceptual model of the study is presented in Figure 5. The study aims to analyze the influence of economic policy uncertainty (EPUC) on foreign direct investment $\left(\mathrm{H}_{1}\right)$ and financial development $\left(\mathrm{H}_{2}\right)$. The study also analyses the role world uncertainty on foreign direct investment $\left(\mathrm{H}_{3}\right)$ and financial development $\left(\mathrm{H}_{4}\right)$.

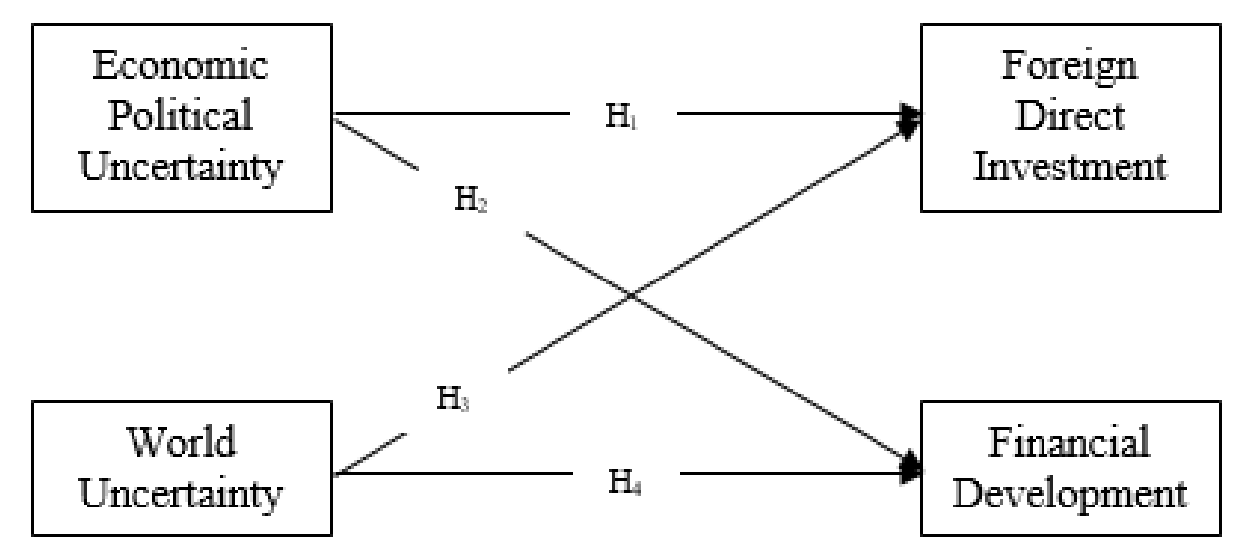

Figure-5. Conceptual Model.

\section{Methodology}

This section presents the data collection techniques, measurement of variables and different econometric techniques to analyze the empirical results of the study. The fundamental purpose of the study is to analyze the impact of EPUC and WUC on FDI and FNDP. In this regard, the study uses time series data. In order to accomplish the fundamental aim of the study, the study gathered the data of France for the period of 1997-2018. The data of EPUC and WUC are collected from www.policyuncertainty.com provided by Naker, Scott; Bloom, Nick; Davis, Stephen and Ahir, Hites; Bloom, Nick; Furcer, Davide. While, the data of FDI and FNDP are gathered from world bank. The study uses EPUC and EUC as independent variables while FDI and FNDP as dependent variables. However, the operationalization or measurement of variables is shown in Table 1.

Table-1. Operationalization or measurement of variables

\begin{tabular}{|c|c|c|c|}
\hline Variable name & Measurement & Reference & Notation \\
\hline \multicolumn{4}{|l|}{ Independent variables } \\
\hline Economic policy uncertainty & Economic policy uncertainty index & Zhu, Jia, and Wu (2019) & EPUC \\
\hline World uncertainty & World uncertainty index & Nguyen and Lee (2021) & WUC \\
\hline \multicolumn{4}{|l|}{ Dependent variables } \\
\hline Foreign direct investment & Net inflows (\% of GDP) & Azam et al. (2012) & FDI \\
\hline Financial development & $\begin{array}{l}\text { Domestic credit to private sector }(\% \text { of } \\
\text { GDP) }\end{array}$ & $\begin{array}{l}\text { Ahmed, Kousar, Pervaiz, and } \\
\text { Ramos-Requena (2020) }\end{array}$ & FNDP \\
\hline
\end{tabular}

Present study uses following two econometric models to accomplish the fundamental purpose of the study

Model 1: FDI $=\beta_{0}+\beta_{1} E P U C_{t}+\beta_{2} W U C_{t}+e$

Model 2: FNDP $=\alpha_{0}+\alpha_{1} E P U C_{t}+\alpha_{2} W U C_{t}+e$

Where: FDI is foreign direct investment, FNDP is financial development, EPUC is economic policy uncertainty, WUC is world uncertainty, $\beta_{0}$ and $\alpha_{0}$ are intercepts, and $\beta_{1}, \beta_{2}, \alpha_{1}$, and $\alpha_{2}$ are the coefficients of EPUC and WUC in models 1 and model 2 respectively, e is error term.

In order to estimate the empirical results of the study, the study first tests the stationarity and order of integration of the modeled variables to choose the best suitable technique for the estimation. To test the stationary properties and order of integration of data, the study used extensively applied augmented dickey fuller (ADF) unit root test. After this, the study applied some diagnostic tests i.e., test of autocorrelation, heteroscedasticity, and multicollinearity to make sure that the data for the present study are free from the econometric errors. After this, the study applies auto regressive distributive lag (ARDL) model to test the hypothesized relations among variables as ARDL is the best suitable approach when the variables are integrated of mixed order. Bounds test is the precondition to apply ARDL approach which tests the co-integrating relation among modeled variables. The study uses Equations 3 and 4 to test the long run relationship between variables.

$\Delta F D I_{t}=\beta_{0}+\sum_{i=1}^{q} \vartheta_{0} \Delta F D I_{t-i}+\sum_{i=0}^{q} \delta_{1} \Delta(E P U C)_{t-i}+\sum_{i=0}^{q} \delta_{2} \Delta(W U C)_{t-i}++\gamma_{0}(F D I)_{t-i}+\beta_{1}(E P U C)_{t-i}+$ $\beta_{2}(W U C)_{t-i}+\mu_{t--3}$

$\Delta F N D P_{t}=\alpha_{0}+\sum_{i=1}^{q} \partial_{0} \Delta F N D P_{t-i}+\sum_{i=0}^{q} \rho_{1} \Delta(E P U C)_{t-i}+\sum_{i=0}^{q} \rho_{2} \Delta(W U C)_{t-i}++\varphi_{0}(F N D P)_{t-i}+$

$\alpha_{1}(E P U C)_{t-i}+\alpha_{2}(W U C)_{t-i} \mu_{t}--4$ 
Where: FDI is foreign direct investment, FNDP is financial development, EPUC is economic policy uncertainty, WUC is world uncertainty, $\beta_{0}$ and $\alpha_{0}$ are intercepts, $\vartheta_{0}, \delta_{1}, \delta_{2}, \partial_{0}, \rho_{1}$, and $\rho_{2}$ are the coefficients of short run for Equations 3 and 4 respectively, $\Delta$ is the difference operator, $\gamma_{0}, \beta_{1}, \beta_{2}, \varphi_{0}, \alpha_{1}$ and $\alpha_{2}$ are the coefficients of long run for Equations 3 and 4 respectively, and $\mu_{t}$ is white noise error term.

Both Equations 3 and 4 used F-statistic to test the long run relationship between the modeled variables for the selected time period. This test involves the testing of the null hypothesis of "no-cointegration". After examining the long run relationship between variables, the study used Equations 4 and 5 to estimate short run parameters and the error correction term (ECT).

$\Delta F D I_{t}=\beta_{0}+\sum_{i=1}^{q} \vartheta_{0} \Delta F D I_{t-i}+\sum_{i=0}^{q} \delta_{1} \Delta(E P U C)_{t-i}+\sum_{i=0}^{q} \delta_{2} \Delta(W U C)_{t-i}++\theta_{0}(E C T)_{t-1}+\mu_{t^{---}} 4$

$\Delta F N D P_{t}=\alpha_{0}+\sum_{i=1}^{q} \partial_{0} \Delta F N D P_{t-i}+\sum_{i=0}^{q} \rho_{1} \Delta(E P U C)_{t-i}+\sum_{i=0}^{q} \rho_{2} \Delta(W U C)_{t-i}++\lambda_{0}(E C T)_{t-1}+\mu_{t^{---}} 5$

Where; $\Delta$ is the first difference operator, $\beta_{0}$ and $\alpha_{0}$ are the intercept term, $\vartheta_{0}, \delta_{1}, \delta_{2}, \partial_{0}, \rho_{1}$ and $\rho_{2}$ are the slope coefficients of short run, $\mathrm{ECM}_{\mathrm{t}-1}$ is the error correction term, which signifies the speed of adjustment or the level of long run equilibrium, and $\mu_{\mathrm{t}}$ is the residual or stochastic error term.

\section{Empirical Results}

\subsection{Descriptive Statistics}

Table 2 shows the results of descriptive statistics. Table represents the mean, median, maximum and minimum values of the data along with skewness and kurtosis. The test statistic of Jarque-Bera is also reported in this Table which is used to test the normality of residuals. The insignificant probability values of Jarque-Bera shows that the data for the current study are normally distributed.

\begin{tabular}{l|c|c|c|c}
\multicolumn{7}{c}{ Table-2. Descriptive Statistics. } \\
\hline Particulars & EPUC & FDI & FNDP & WUC \\
\hline Mean & 155.7398 & 2.9719 & 87.6970 & 0.1822 \\
\hline Median & 126.9852 & 2.2960 & 92.5250 & 0.1579 \\
\hline Maximum & 317.1186 & 12.8815 & 107.6418 & 0.4264 \\
\hline Minimum & 37.6033 & 0.2032 & 68.3989 & 0.0562 \\
\hline Std. Dev. & 88.8044 & 2.9345 & 11.8812 & 0.0993 \\
\hline Skewness & 0.3841 & 2.4268 & -0.1458 & 1.0384 \\
\hline Kurtosis & 1.8490 & 8.2244 & 1.6861 & 3.3047 \\
\hline Jarque-Bera & 1.8353 & 1.7351 & 1.7348 & 0.2229 \\
\hline Probability & 0.3994 & 0.1000 & 0.4200 & 0.1210 \\
\hline Where: FDI is foreign direct investment, FNDP is financial development, EPUC is economic policy uncertainty, and
\end{tabular}

WUC is world uncertainty.

\subsection{ADF Test of Stationarity and Multicollinearity}

Present study applies extensively used Augmented Dicky Fuller (ADF) unit root test to know about the order of integration and the stationarity properties of the data. The test is applied on level and first difference for two cases i.e., with intercept, and with intercept and trend. Test is having the null hypothesis of the "non-stationary series". Results in Table 3 (Panel A) show that the test statistic of EPUC and WUC are insignificant at level in both cases (i.e., with intercept, and with intercept and trend). This depicts the problem of non-stationary in these variables at level. However, the test statistic becomes significant at first difference in both cases by rejecting the null hypothesis of non-stationary series. This depicts that the EPUC and EUC are stationary at first difference and integrated of order 1. On the contrary, the test statistic of FDI and FNDP are significant at both (level and first difference) in both the cases. This implies that FDI and FNDP are free from the problem of unit root and integrated of order 0 i.e., I (0). As some of the variables are integrated of I (0), and some are integrated of I (1), hence, it is concluded that the variables of the present study are integrated of mix order.

Table 3 (Panel B) shows the results of correlation matrix which is used to detect the problem of multicollinearity. Results depict that the data for the current study are free from the problem of multicollinearity as the coefficient of correlation between two any variables is less than 0.50.

Table-3. ADF Unit Root and Multicollinearity

\begin{tabular}{|c|c|c|c|c|c|c|}
\hline \multicolumn{7}{|c|}{ Panel A: ADF Unit Root Test } \\
\hline \multirow[b]{2}{*}{ Variables } & \multicolumn{3}{|c|}{ Level } & \multicolumn{2}{|c|}{ First Difference } & \multirow[b]{2}{*}{ Decision } \\
\hline & Intercept & \multicolumn{2}{|c|}{ Intercept and trend } & Intercept & Intercept and trend & \\
\hline EPUC & -2.1958 & \multicolumn{2}{|c|}{-2.1600} & $-5.3025^{* * *}$ & $-5.2095^{* * *}$ & $\mathrm{I}(1)$ \\
\hline WUC & -1.3370 & \multicolumn{2}{|c|}{-1.2161} & $-3.3755^{* *}$ & $-3.2301 * *$ & $\mathrm{I}(1)$ \\
\hline FDI & $-3.2125^{* *}$ & \multicolumn{2}{|c|}{$-3.9845^{* * * *}$} & $-4.8353 * * *$ & $-4.9745 * * *$ & $\mathrm{I}(0), \mathrm{I}(1)$ \\
\hline FNDP & $-3.4876^{* * * *}$ & \multicolumn{2}{|c|}{$-3.4825^{* * * *}$} & $-4.1190 * * *$ & $-4.8355^{*} * *$ & $\mathrm{I}(\mathrm{O}), \mathrm{I}(1)$ \\
\hline \multicolumn{7}{|c|}{ Panel B: Multicollinearity } \\
\hline \multicolumn{2}{|c|}{\begin{tabular}{l|l} 
Variables & \\
\end{tabular}} & \multicolumn{2}{|c|}{ EPUC } & FNDP & \multicolumn{2}{|l|}{ WUC } \\
\hline EPUC & \multicolumn{3}{|c|}{1} & & & \\
\hline \multicolumn{2}{|l|}{ FDI } & \multicolumn{2}{|c|}{-0.1908} & & & \\
\hline \multicolumn{2}{|l|}{ FNDP } & \multicolumn{2}{|r|}{-0.6469} & 1 & & \\
\hline \multicolumn{2}{|l|}{ WUC } & \multicolumn{2}{|r|}{-0.3124} & 0.1024 & \multicolumn{2}{|l|}{1} \\
\hline
\end{tabular}

is level of significance at $5 \%$ and $10 \%$ respectively.

\subsection{Autocorrelation, Heteroscedasticity and Bounds Co-Integration Test}

Results of autocorrelation, heteroscedasticity and bound test for both of the study model are presented in Table 4. Both tests are having the hull hypothesis of "no serial correlation" and "no heteroscedasticity" respectively. The 
insignificant p-values reported in Panel A and Panel B indicating the acceptance of null hypothesis which specifies that the data for the present study are free from the econometrics problem like auto/serial correlation and heteroscedasticity. The study applies bounds cointegration test to determine the cointegrating relation among modeled variables. The test is applied for both the models. Results of Table 4 (Panel C) indicate the presence of long run relation between the variables of both models as the value of $\mathrm{F}$-statistic ( 8.823 and 9.945 respectively) is greater than the upper bounds at $10 \%, 5 \%$ and $1 \%$ level of significance. Hence, the respective study concluded that the chosen variables of the study move together in long run for the period of 1997-2018.

Table-4. Test of Autocorrelation and Heteroscedasticity

\begin{tabular}{|c|c|c|c|c|c|c|}
\hline \multicolumn{7}{|c|}{ Panel A: Auto Correlation } \\
\hline \multicolumn{4}{|c|}{ Model 1} & \multicolumn{3}{|l|}{ Model 2} \\
\hline \multirow{2}{*}{$\begin{array}{l}\text { Breusch-Godfrey } \\
\text { Serial } \\
\text { Correlation }\end{array}$} & $\begin{array}{c}\text { Test } \\
\text { statistic }\end{array}$ & P-value & Decision & Test statistic & P-value & Decision \\
\hline & 1.9833 & 0.1647 & No serial correlation & 0.2345 & 0.1773 & No serial correlation \\
\hline \multicolumn{7}{|c|}{ Panel B: Heteroscedasticity } \\
\hline \multicolumn{4}{|c|}{ Model 1} & \multicolumn{3}{|l|}{ Model 2} \\
\hline \multirow[t]{2}{*}{$\begin{array}{l}\text { Breusch-Pagan- } \\
\text { Godfry HSK }\end{array}$} & $\begin{array}{c}\text { Test } \\
\text { statistic }\end{array}$ & P-value & Decision & Test statistic & P-value & Decision \\
\hline & 1.8938 & 0.3326 & No heteroscedasticity & 0.1534 & 0.2413 & No heteroscedasticity \\
\hline \multicolumn{7}{|c|}{ Panel C: Bound Test } \\
\hline \multicolumn{2}{|c|}{ F-Bounds Test } & Model 1 & Model 2 & \multicolumn{3}{|c|}{ Null Hypothesis: No levels relationship } \\
\hline \multicolumn{2}{|l|}{ Test Statistic } & Value & Value & Significance & $\mathrm{I}(\mathrm{O})$ & \begin{tabular}{l|l|} 
& $\mathrm{I}(1)$ \\
\end{tabular} \\
\hline \multicolumn{2}{|l|}{ F-statistic } & 8.623 & 9.945 & $10 \%$ & 4.19 & 5.06 \\
\hline \multirow[t]{2}{*}{ K } & & 2 & \multirow[t]{2}{*}{2} & $5 \%$ & \multirow{2}{*}{$\begin{array}{l}4.87 \\
6.34\end{array}$} & 5.85 \\
\hline & & & & $1 \%$ & & 7.52 \\
\hline
\end{tabular}

\subsection{Hypotheses Testing}

Present study uses ARDL to estimate the empirical results. Results are reported in Table 5. Panel A of Table 5 shows the long run association between variables, while panel B shows the speed of adjustment between variables. In panel A, the coefficient of EPUC in model 1 shows the negative and significant relationship between EPUC and FDI at the level of $1 \%$, while the coefficient of EPUC in model 2 shows the negative and significant relationship between EPUC and FNDP at 5\% level of significance. Result implies that 1-unit of increase in EPUC results in a decrease of 3.5540 units in FDI while 5.7845 units of FNDP in long run. Hence, the $1^{\text {st }}$, and $3^{\text {rd }}$ hypotheses of the study are supported. On the other hand, the coefficients of WUC in model 1 and model 2 reveal the negative impact of WUC on FDI and FNDP. Results show that 1-unit of increase in WUC result in a decrease of 2.9845 and 3.9853 units in FDI and FNDP in long run at the level of $5 \%$ and $1 \%$, respectively. Hence, the $2^{\text {nd }}$ and $4^{\text {th }}$ hypotheses of the study are also supported. In panel B, the coefficient of ECT is negative and highly significant at the level of $1 \%$. Result shows that $74.65 \%(63.44 \%)$ inconsistency between the long term and short term FDI (FNDP) will be corrected within a year. Finally, the values of adjusted R-squares of model 1 and model 2 show that EPUC and WUC collectively explained $66.63 \%$ variations in FDI while 69.57\% variations in FNDP.

\begin{tabular}{|c|c|c|c|c|c|c|}
\hline \multirow[t]{2}{*}{ Variables } & \multicolumn{2}{|c|}{ Model 1 (DV: FDI) } & \multirow[t]{2}{*}{ Decision } & \multicolumn{2}{|c|}{ Model 2 (DV: FNDP) } & \multirow[t]{2}{*}{ Decision } \\
\hline & Coefficient & $p$-value & & Coefficient & $p$-Value & \\
\hline \multicolumn{7}{|c|}{ Panel A: Long run results } \\
\hline EPUC & -3.5540 & $0.0034 * * *$ & H1: Supported & -5.7845 & $0.0263 * *$ & Hs: Supported \\
\hline WUC & -2.9845 & $0.0453^{* * *}$ & H2: Supported & -3.9853 & $0.000 * * *$ & H4: Supported \\
\hline \multicolumn{7}{|c|}{ Panel B: Short run/ECM regression } \\
\hline ECT & -0.7465 & $0.000^{* * * *}$ & -- & -0.6344 & $0.0000^{* * * *}$ & -- \\
\hline $\mathrm{R}^{2}$ & \multicolumn{2}{|c|}{0.7475} & -- & \multicolumn{3}{|c|}{0.7898} \\
\hline Adj. $\mathrm{R}^{2}$ & \multicolumn{2}{|c|}{0.6663} & -- & \multicolumn{3}{|c|}{0.6957} \\
\hline
\end{tabular}

****** is level of significance at $5 \%$ and $10 \%$ respectively.

\section{Conclusion}

Since the publication of "The Age of Uncertainty" in 1977, many major events have been occurred that results in an economic and political uncertainty around the world. This uncertainty is highly aligned with the fact that we exist in the "hyper-connected" world, where an event which arises in one part of the world will definitely have an influence on the other part of the world. Evidences reveals that financial crises of 2008, Arab springs of 2012, and European sovereign debt crises of 2010 are the underlying causes of increased economic, political and world uncertainties around the globe. These uncertainties are imposing adverse and detrimental effects on the whole economy, specifically on the financial sector of France. The outbreak of corona virus in the last quarter of 2019 makes the situation more worst, specifically for the case of France. The outbreak of this virus results a drastic reduction in liquidity and solvency of French corporations. The inflows of FDI in France also reduces by $17 \%$ during the outbreak of virus. However, after analyzing the situation of WUC and EPUC in France, Present study propose that it is crucial to examine the role of EPUC and WUC on the FDI and FNDP on France. For this purpose, the study gathers the data of France for the period of 1997-2018. The study applied ARDL bound testing approach of estimation. Results of the study show the negative impact of WPUC and WUC on FDI and FNDP of France. Results are aligned with prior studies (Avom et al., 2020; Caglayan \& Xu, 2019; Choi et al., 2021; Li \& Zhong, 2020). Findings imply that world and economic policy uncertainty are very detrimental for the foreign inflows and financial development of the France. Therefore, the study suggests that the France government should monitor the source and size of uncertainty shock while formulating different economic policies. 


\section{References}

Abaidoo, R. (2019). Policy uncertainty and dynamics of international trade. Journal of Financial Economic Policy, 11(1), 101-120.Available at: https://doi.org/10.1108/jfep-02-2018-0034.

Ahmed, F., Kousar, S., Pervaiz, A., \& Ramos-Requena, J. P. (2020). Financial development, institutional quality, and environmental degradation nexus: New evidence from asymmetric ARDL co-integration approach. Sustainability, 12(18), 1-21.Available at: https://doi.org/10.3390/su12187812.

Al-Thaqeb, S. A., \& Algharabali, B. G. (2019). Economic policy uncertainty: A literature review. The Journal of Economic Asymmetries, 20, e00133.Available at: https://doi.org/10.1016/j.jeca.2019.e00133.

Albulescu, C. T., Demirer, R., Raheem, I. D., \& Tiwari, A. K. (2019). Does the US economic policy uncertainty connect financial markets? Evidence from oil and commodity currencies. Energy Economics, 83, 375-388.Available at: https://doi.org/10.1016/j.eneco.2019.07.024.

Ashraf, B. N., \& Shen, Y. (2019). Economic policy uncertainty and banks' loan pricing. Journal of Financial Stability, 44, 100695.Available at: https://doi.org/10.1016/j.jfs.2019.100695.

Avom, D., Njangang, H., \& Nawo, L. (2020). World economic policy uncertainty and foreign direct investment. Economics Bulletin, 40(2), $1457-1464$.

Azam, M., Khan, M. A., \& Iqbal, N. (2012). Impact of political risk and uncertainty on FDI in South Asia. Transition Studies Revierw, 19(1), 5977.Available at: https://doi.org/10.1007/s11300-012-0230-x.

Busse, M., \& Hefeker, C. (2007). Political risk, institutions and foreign direct investment. European Journal of Political Economy, 23(2), 397415.Available at: https://doi.org/10.1016/j.ejpoleco.2006.02.003.

Caglayan, M., \& Xu, B. (2019). Economic policy uncertainty effects on credit and stability of financial institutions. Bulletin of Economic Research, 71(3), 342-347.Available at: https://doi.org/10.1111/boer.12175.

Canh, N. P., Binh, N. T., Thanh, S. D., \& Schinckus, C. (2020). Determinants of foreign direct investment inflows: The role of economic policy uncertainty. International Economics, 161, 159-172.Available at: https://doi.org/10.1016/j.inteco.2019.1 1.012.

Choi, S., Furceri, D., \& Yoon, C. (2021). Policy uncertainty and foreign direct investment. Review of International Economics, 29(2), $195-227$.

Debata, B., \& Mahakud, J. (2018). Economic policy uncertainty and stock market liquidity: Does financial crisis make any difference? Journal of Financial Economic Policy, 10(1), 112-135.Available at: https://doi.org/10.1108/jfep-09-2017-0088.

Demir, E., \& Ersan, O. (2018). The impact of economic policy uncertainty on stock returns of Turkish tourism companies. Current Issues in Tourism, 21(8), 847-855.Available at: https://doi.org/10.1080/13683500.2016.1217195.

Drobetz, W., El Ghoul, S., Guedhami, O., \& Janzen, M. (2018). Policy uncertainty, investment, and the cost of capital. Journal of Financial Stability, 39, 28-45.Available at: https://doi.org/10.1016/j.jfs.2018.08.005.

French, J. J., \& Li, W. X. (2021). Economic policy uncertainty and fund flows to the United States. Finance Research Letters, 102126. Available at: https://doi.org/10.1016/j.frl.2021.102126.

Godil, D. I., Sarwat, S., Sharif, A., \& Jermsittiparsert, K. (2020). How oil prices, gold prices, uncertainty and risk impact Islamic and conventional stocks? Empirical evidence from QARDL technique. Resources Policy, 66, 101638.Available at: https://doi.org/10.1016/j.resourpol.2020.101638.

Goodell, J. W., McGee, R. J., \& McGroarty, F. (2020). Election uncertainty, economic policy uncertainty and financial market uncertainty: A prediction market analysis. Journal of Banking $\mathcal{E}^{\circ}$ Finance, 110, 105684.Available at: https://doi.org/10.1016/j.jbankfin.2019.105684.

Guo, A., Wei, H., Zhong, F., Liu, S., \& Huang, C. (2020). Enterprise sustainability: Economic policy uncertainty, enterprise investment, and profitability. Sustainability, 12(9), 1-22.Available at: https://doi.org/10.3390/su12093735.

Hu, Z., Kutan, A. M., \& Sun, P.-W. (2018). Is US economic policy uncertainty priced in China's A-shares market? Evidence from market, industry, and individual stocks. International Review of Financial Analysis, 57, 207-220.Available at: https://doi.org/10.1016/j.irfa.2018.03.015.

Li, Z., \& Zhong, J. (2020). Impact of economic policy uncertainty shocks on China's financial conditions. Finance Research Letters, 35, 101303.Available at: https://doi.org/10.1016/j.frl.2019.101303.

Liow, K. H., Liao, W.-C., \& Huang, Y. (2018). Dynamics of international spillovers and interaction: Evidence from financial market stress and economic policy uncertainty. Economic Modelling, 68, 96-116.Available at: https://doi.org/10.1016/j.econmod.2017.06.012.

Liu, P., \& Dong, D. (2020). Impact of economic policy uncertainty on trade credit provision: The role of social trust. Sustainability, 12(4), 124.

Mian, A., \& Sufi, A. (2010). The great recession: Lessons from microeconomic data. American Economic Review, 100(2), 51-56.Available at: https://doi.org/10.1257/aer.100.2.51.

Nguyen, Q., Kim, T., \& Papanastassiou, M. (2018). Policy uncertainty, derivatives use, and firm-level FDI. Journal of International Business Studies, 49(1), 96-126.Available at: https://doi.org/10.1057/s41267-017-0090-z.

Nguyen, C. P., \& Lee, G. S. (2021). Uncertainty, financial development, and FDI inflows: Global evidence. Economic Modelling, 99, 105473.Available at: https://doi.org/10.1016/j.econmod.2021.02.014.

Phan, D. H. B., Iyke, B. N., Sharma, S. S., \& Affandi, Y. (2021). Economic policy uncertainty and financial stability-is there a relation? Economic Modelling, 94, 1018-1029.Available at: https://doi.org/10.1016/j.econmod.2020.02.042.

Shen, H., Zhang, M., Liu, R., \& Hou, F. (2020). Economic policy uncertainty and corporate innovation: Evidence from China. Asian Economics Letters, 1(1), 1-6.

Shi, Q., Qiu, W., \& Fan, Y. (2020). Economic policy uncertainty and the distribution of business operations between parent companies and their subsidiaries. Emerging Markets Finance and Trade, 56(2), 427-456.Available at: https://doi.org/10.1080/1540496x.2019.1700363.

Wang, X., Luo, Y., Wang, Z., Xu, Y., \& Wu, C. (2021). The impact of economic policy uncertainty on volatility of China's financial stocks: An empirical analysis. Finance Research Letters, 39, 101650.Available at: https://doi.org/10.1016/j.frl.2020.101650.

Wu, J., Zhang, J., Zhang, S., \& Zou, L. (2020). The economic policy uncertainty and firm investment in Australia. Applied Economics, 52(31), 3354-3378.Available at: https://doi.org/10.1080/00036846.2019.1710454.

Zhao, X. (2020). Do the stock returns of clean energy corporations respond to oil price shocks and policy uncertainty? Journal of Economic Structures, 9(1), 1-16.Available at: https://doi.org/10.1 186/s40008-020-00229-x.

Zhu, J., Jia, F., \& Wu, H. (2019). Bankruptcy costs, economic policy uncertainty, and FDI entry and exit. Review of International Economics, $27(4), 1063-1080$.

Citation: Francois Smith (2021). Uncertainty, Financial Development and FDI Inflows: France Evidence. Asian Business Research Journal, 6: 7-13.

\section{History:}

History:
Received: 19 February 2021
Revised: 14 June 2021

Accepted: 12 July 2021

Published: 10 August 2021

Licensed: This work is licensed under a Creative Commons

Attribution 3.0 License (cc)

Publisher: Eastern Centre of Science and Education

Eastern Centre of Science and Education is not responsible or answerable for any loss, damage or liability, etc. caused in relation to/arising out of the use of the content. Any queries should be directed to the corresponding author of the article.
Funding: This study received no specific financial support.

Competing Interests: The author declares that there are no conflicts of interests regarding the publication of this paper.

Transparency: The author confirms that the manuscript is an honest, Transparency: The author confirms that the manuscript is an honest,
accurate, and transparent account of the study was reported; that no vital features of the study have been omitted; and that any discrepancies from the features of the study have been omit
study as planned have been explained.

Ethical: This study follows all ethical practices during writing. 